\title{
指標植物を用いた大気污染評価 \\ 一観察手法によるモニタリングの現状一
}

相 原 敬 次*

\section{はじめに}

一般的に植物は，環境の変化に敏感に反応し，そ のサインをいろいろな形で表している．植物のこの ような特徵を利用して環境の状態を評価することを 植物指標という. 理化学機器によって環境を評価す る技術も，一方では格段に進歩しているが，植物を 通して大気污染や自然環境を評価することの重要性 も一段と増している．植物指標の歴史は古く，その 必要性, 長所, 短所等の内容は, いくつかの成書1),2),3) に詳しくまとめられている.

大気污染評価のための植物指標も古くから様々な 種類や手法が提案されている. 植物指標には, 単に 植物そのものを観察, 調査する方法から, 植物を対 象あるいは材料にして, 理化学的な計器や装置によ $\eta$, 化学成分や形態を分析, 測定する方法等まで広 くある.今回は，指標植物を簡易に観察，調査する 方法のうち, とりわけ実際的に，かつ長期的に大気 污染評価のためのモニタリングを試みている国内の 事例と現状について述べる。

\section{1．植物の葉の可視被害の観察による方法}

植物の葉は, 気孔を通じて呼吸や蒸散, 光合成を している，そのため大気中の污染物質によって，葉 の細胞組織は, 異常を起こし，その表面に白色や褐 色の斑点を生じ, 目に見える特徵的な被害症状を呈 する，かつては，発生源の近傍に生育する植物の葉 に，典型的な可視被害症状を呈する事例がよく見ら れた。いおう酸化物，フッ素化合物，塩素化合物な どの大気污染物質による影響や被害症状に関して写 真集 ${ }^{4), 5)}$ もとめられている. 可視被害の症状の状況 から, 污染質の種類や被害発生のいき值濃度の推定

* 神奈川県環境科学センター

Keiji AIHARA
などを大まかに知ることが出来, 農作物の被害の原 因の特定や発生源対策に利用されてきた(表 1)。こ のようなフッ素化合物, 塩素化合物など局地的な污 染質による可視被害症状は，工場などの発生源対策 が進んできており，現在では，偶発的な事故や特別 な場合を除いてはほとんど確認されることが少なく なっている，しかし，今日でもなお，夏になると慢 性的に関東地方などを中心に観察されるものに，広 域的な 2 次污染物質である光化学オキシダントによ る植物葉の可視被害がある.

国内における光化学スモッグ污染の発端となった 立正高校事件（1970年；昭和45年）のおこる年の以 前から, 国内の夕バコの葉に原因不明の生理的斑点 病とよばれる症状が認められていた。そして，関東 地方一円に広がったホウレンソウやコマツナなどの 多くの農作物に現れた原因不明の被害症状も，光化 学オキシダントによるものであることが確かめられ た.この光化学オキシダントによる可視被害は，一 方では, 光化学オキシダントによる大気污染の評価 の良い植物指標となり，アサガオ，サトイモ，ペチ ュニアに代表される植物が使われている.1974年(昭 和49年）～1976年（昭和51年）には全国的な調査も 実施され，污染による被害の全国的な広がりを確認 したり，東京都の立川市のように早い頃から市民， 行政機関, 試験研究機関が協力した調査なども実施 されてきた．現在でもなお，モニタリング調査がな されたり, 近年の環境教育・学習のための, わかり やすい教材としても利用されている。

国内で，既に，20年以上にもわたって組織的に行 われているモニタリング調査に,「光化学スモッグに よる植物影響調査」がある ${ }^{6)}$. 1974年 (昭和49年) か ら関東地方の埼玉県，千葉県，東京都，神奈川県の 南関東の自治体で始めた調查は, 現在では, 茨城県, 栃木県, 群馬県, 長野県, 山梨県, 静岡県を加え11 
表 1 おもな大気污染物質による植物可視被害症状と急性症状発生濃度いき值 ${ }^{1}$

\begin{tabular}{|c|c|c|}
\hline 大気污染物質 & $\begin{array}{l}\text { 植物への急性症 } \\
\text { 状発生いき值 }\end{array}$ & $\begin{array}{lllllll}\text { 极 も } \text { な 可 視 症 状 } \\
\end{array}$ \\
\hline $\begin{array}{c}\text { 二酸化硫黄 } \\
\left(\mathrm{SO}_{2}\right)\end{array}$ & $0.1-1.5 \mathrm{ppm}$ & $\begin{array}{l}\text { 葉脈間不定形斑点, 葉縁部黄褐色斑点 (広葉), 先端・中央部の褐 } \\
\text { 変 (針葉), 一般に大形斑点 }\end{array}$ \\
\hline $\begin{array}{c}\text { 二酸化窒素 } \\
\left(\mathrm{NO}_{2}\right) \\
\end{array}$ & $10-50 \mathrm{ppm}$ & 二酸化硫黄に類似 \\
\hline $\begin{array}{c}\text { オ゙ ン } \\
\left(\mathrm{O}_{3}\right)\end{array}$ & $0.05-0.2 \mathrm{ppm}$ & $\begin{array}{l}\text { 葉の表面に均一な白色〜褐色斑点, ネクホシス, 早期落葉, 葉の } \\
\text { 漫曲 }\end{array}$ \\
\hline PAN & $0.05 \mathrm{ppm}$ & $\begin{array}{l}\text { 葉の裏側に銀色〜青銅色の光った大形斑点（全体として横バンド } \\
\text { 状） }\end{array}$ \\
\hline $\begin{array}{c}\text { エチレン } \\
\left(\mathrm{CH}_{2}=\mathrm{CH}_{2}\right)\end{array}$ & $0.05-1.0 \mathrm{ppm}$ & $\begin{array}{l}\text { 葉の上偏生長, 開花異常 (めしべ退化, 雄花の雌花化など), 落果, } \\
\text { 早期葉落, 黄化促進 }\end{array}$ \\
\hline $\begin{array}{l}\text { フッ化水素 } \\
(\mathrm{HF})\end{array}$ & $5-10 \mathrm{ppb}$ & 葉先端, 周縁クロロシス, ネクソシス \\
\hline $\begin{array}{l}\text { 塩 素 } \\
\left(\mathrm{Cl}_{2}\right)^{-}\end{array}$ & $0.1-0.3 \mathrm{ppm}$ & 葉脈間漂白斑点, 葉先端黄変 \\
\hline
\end{tabular}

の自治体での共同調査になっており, 調査地点も 1995年（平成 7 年）は，74地点になっている.

この調査は, 光化学スモッグによって発生する植 物被害の程度が関東地方の中でどのような広がりを もち，年によってどのような変化をするかといった ことを経年的にモニタリングし，植物の側から大気 環境を評価しようとする目的をもっている．そのた め調査の方法や項目は，あらかじめ決めておき，途 中で変更しないように一貫性をもたせている。（表 2, 表 3 ）指標植物としてアサガオ，サトイモ，ぺ チュニアを選んでいるが, これまでには，ポプラ， 水稲, アルファルファなどの指標植物を用いたモニ タリング手法の検討もおこなっている.

光化学スモッグによる植物被害のモニタリングを 広い範囲にわたり，しかも組織的に長期間継続して いるこのような調査は，わが国では他に例がない. 最近の結果をみても, アサガオの光化学オキシダン 卜による可視被害は，相変わらず関東地方の中央部 で大きく，長野県側や山梨県方面にも広範囲に生じ ていることが確認されており, 植物からみた光化学 スモッグ污染は，未だ改善されていないことがわか る.

\section{2. 蘚苔植物 (類) や地衣植物 (類) 等の 着生植物による方法}

この方法は，一般的に「コケ」と呼ばれている着 生植物である蘚苔植物や地衣植物を指標植物にして 生育相や生育確認を調査することによって大気污染
の評価をする方法である.「コケ」は, 蘚苔植物, 地 衣植物, 気生の藻植物, 高等植物の一部までを含み, 樹皮, 岩石に着生したり, 地上に生育する微小な植 物の総称である。

図鑑》によれば，「蘚苔植物は配偶体が緑色で，造 卵器と造精器を生じ, 多くの場合に茎と葉に分化し, 胞子体は退化して，配偶体の上についている陸上植 物群を指す。地衣植物は, 葉, 茥の分化がなく, 黄 緑色または灰緑色で, 菌糸がその体ををつくり, 藻 植物をその中に取り込んでいる.」と記されている. このように，両者の区別は，分かりにくいが，一般 的に着生蘚苔植物は, 日陰や湿潤な場所に生育する のに対して, 地衣植物は, 日当りや風通しの良い場 所に生育する傾向にある。いずれも樹木や岩石に着 生する植物で, その性質や構造から大気污染による 影響を受け易いことからよい指標植物とされてい る.

垰田 ${ }^{8}$ は，1969年 (昭和44年) から1971年 (昭和 46 年）にかけて東京都内における着生鮮苔植物の調査 を実施し，その種類の構成と多さによって,「正常地 帯」「移行帯」,「着生砂漠」に分類した大気污染度 図を作成している。これによれば，山の手線以東か ら東側にかけては, 全く蘚苔植物の生育を認めない 地域，すなわち「着生砂漠」地域が確認されていた。 当時の大気污染の状況は，いおう酸化物や降下ばい じんなどの工場から排出される污染物質の濃度が高 く，これらの影響が直接に反映されていたものと見 ることができる. 最近, 菅, 大橋 ${ }^{9}$ は, この約 20 年前 
の調査結果をふまえて, 都内において同様の着生蘚 苔植物の調査を実施している。その結果によれば, 都心部を含む東部の「着生砂漠」とされた地域で, 蘚苔植物の生育と種の増加を確認しており, それは, 二酸化硫黄濃度などによる大気污染の状況が改善さ れてきていることを反映しているものと評価してい る(図一2).しかし, 郊外の地域では種類数の増加 傾向が顕著ではなく乾燥化などの都市化による影響 のあることも示唆している.

兵庫県においては, 光木 ${ }^{10)}$ が, 神戸, 東播磨および 西播磨の 3 地域における着生蘚苔植物の調査を実施 し，1975年 (昭和50年) 1976年 (昭和51年)，1972 年（昭和 47 年） 1981（昭和58年）年頃の調査結果 と比較し, 大気環境の評価の推移をみている。その 結果，早くから都市化と工業化の進んだ神戸地域と 東播磨地域においては，以前に比較して出現種数の 増加した地点が多く, 一方西播磨地域では出現種数 の減少した地点が多いことを認めている．また着生 蘚苔植物による数值化, すなわち大気污染環境評価 指数 (EIAQ) を自ら検討改良し，この EIAQ 指数に よって推移をみた結果, 3 地域とも上昇傾向にあり, 特に神戸地域で顕著であることを確認している。し かし, 東播磨地域や西播磨地域の一部では, 指数值 の下がった地点もあり, 地点によっては悪化の傾向

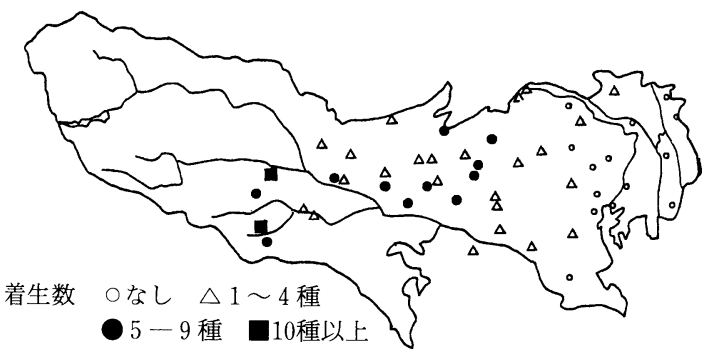

樹木着生蘇苔類の種数分布(垰田の調査より；1969-71)

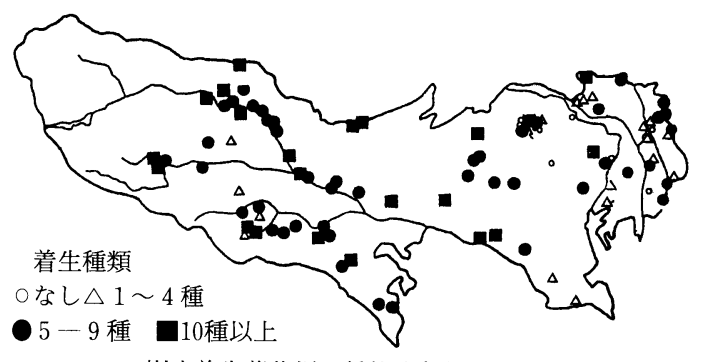

樹木着生蘇苔類の種数分布 (1989-1992)

图一2 東京都における樹木着生蘚苔植物の種数分布の 推移 ${ }^{9}$
にあることも認めている.

中川 ${ }^{11)}$ ら, 着生地衣植物の調査を行い, 兵庫県下 における1984年 (昭和59年) から1994年 (平成 6 年) までの約 10 年間の変化ついて, 大気清浄度指数 (IAP) や種ごとの被度 (生育量), および大気污染 との関係を検討している，その結果，IAP 值からみ た大気環境は, 阪神地域 $>$ 淡路地域 $>$ 東播磨地域 $>$ 西播磨地域 $>$ 神戸地域 $>$ 丹波地域の順に良く，この うち工業地域である阪神地域，神戸地域は，若干の 被度の回復が認められたのに対して他の地域では前 回調査時に比較してやや悪化している傾向であるこ とを認めている。

福岡県においては，1978年（昭和53年）から1994 年 (平成 6 年) までに 4 年から 5 年間隔で着生地衣, 鮮苔植物の生育相調査を継続して実施し, IAP 指数 值から環境評価の推移をとりまとめている ${ }^{12)}$ ．その 結果, 従来から大気環境も良好であった福岡, 久留 米, 行橋・苅田, 豊前の 4 地区では, その状態が維 持されており, 北九州, 大牟田地区の工業地域では 調査回を重ねるごとに大気環境が良好になってきて いる状況を確認している．しかし，この 2 地区は， 他の良好な 4 地区に比較してなお評価値が低い状況 で，とりわけ北九州地区は，大牟田地区に比較して 回復が遅い状況にあるということである。また，福 岡地区や久留米地区においては良好な状況にあるも のの, 近年の交通量の増加や市の周辺部での宅地化 による影響も考えられ，継続調査が必要であるとし ている.

このように，着生植物を指標として，公害による 大気污染が顕著であった時期からの経年的なモ二夕 リングの調査結果が最近相次いで報告されている. その結果, 過去の劣悪な大気環境が改善された地域 では，それにともなって着生植物の生育相が回復し ていることを確認している.

これまでに実施されてきた着生「コケ」植物の調 査手法は, 生態学的手法による生育相（フロラ）調 査が多かった。これは，種の分布状況など詳細な情 報が得られ，また I A P 指数などの数值化も可能で あり, 定量的な評価が可能となる。しかしながら, 調査そのものは「観察」という，安価な手法にもか かわらず，その実施には，種の判別，確認という専 門的な経験と熟練が不可欠であり，そのために，調 查スタッフや調査地域が限定されている．植物指標 における野外調査は，専門的な経験と技術を用いて 
より多くの詳細な情報を得ることも必要であるが, 一方簡易な手法によってより多くの調査数や地点を 得ることも環境モニタリングにおける重要な要素の ひとつである.

神奈川県においては，住民や市民を交えた簡易な 地衣植物の生育確認による調查を実施した。すなわ

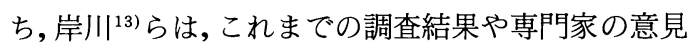
をもとに, ウメノキゴケ, キウメノキゴケ, マツゲ ゴケ, オオマツゲゴケ, ヒモウメノキゴケ, ハクテ ンゴケの仲間，カラクサゴケの仲間をまとめて「ウ メノキゴケ類」とし，キイとなる種（指標種）を選 定した。これらは，大気污染に弱いとされており， 大型の葉状地衣植物で, 個々の種の判定は困難でも 初心者による識別が可能であるとの理由から選定さ れた.「ウメノキゴケ類」の写真を添付したパンフレ ットや簡単な調査票を作成した(表 4 )。このように して, 調査に関心のある一般県民を募り, 専門家に よる講習会, 観察会を経て, 共同で「ウメノキゴケ 類」の生育確認調査を実施した。1988年 (昭和63年) から1990年 (平成 2 年) までに県下で500地点の調査 票が得られた。これによれば, 横浜, 川崎のほとん どの地域, 県中央部の一部の地域でウメノキゴケの 生育は確認されなかったが, 山沿いの地域から山間

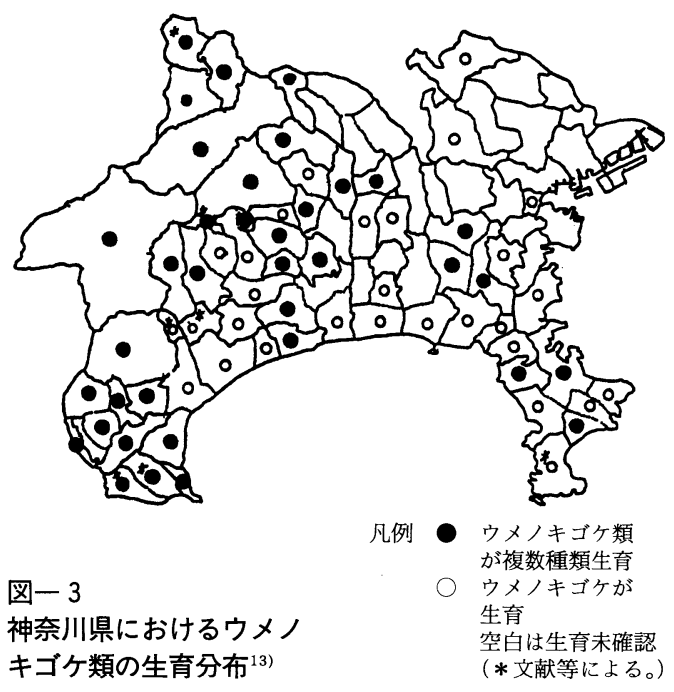

地では複数種が生育していることが確認された（図 $-3)$.

また，神奈川県市の大気污染共同調查体である神 奈川県臨海地区大気污染調査協議会 ${ }^{14)}$ や東京都の大 橋, 菅 ${ }^{15}$ は，「ウメノキゴケ類」のほかさらに比較的 大気污染に強いといわれているコフキジリナリアや レプラゴケを指標種として加えて調査をしている.
表 4

ウメノキゴケ類の調査票 ${ }^{13)}$

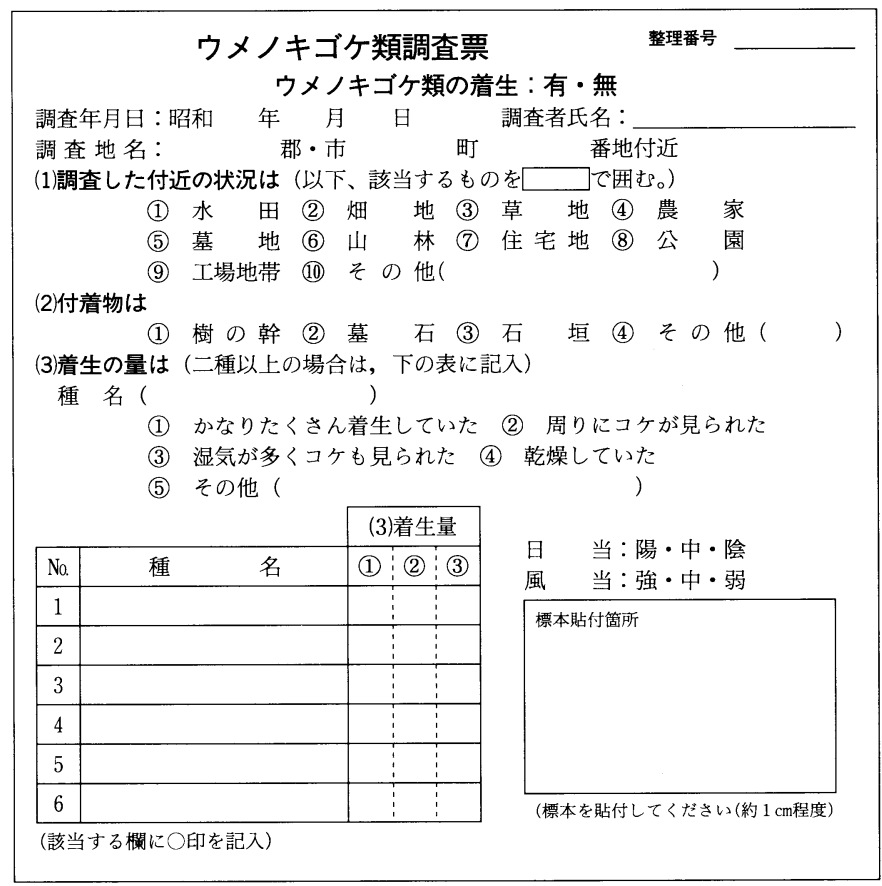


このような, 特定の指標種を用いた手法は, 着生植 物を用いた植物指標をより簡易にし，一般化出来る ものとして期待される。

\section{3. 樹木の外見的な観察を用いる方法}

樹木は，長期間同じ場所で生育しているため，総 合的な環境の状態や，その経年的な変化を反映して いる. そのため, 大気污染などの人為的な環境悪化 の指標植物として利用されている。これは，自然状 態に生育している樹木の外見的な状態を目視によっ て観察し, 決められた基準にしたがって点数評価に より指標とするものである ${ }^{16)}($ 表 5 )。指標は,「活性 度」,「健康度」,「活力度」,「樹勢度」とも呼ばれた り，あるいは「衰退度」というょうに逆の評価をす る場合もある。「活力度」などの場合は, 点数が高い ほどよい評価であるが, 「衰退度」は, 点数が高いほ ど悪い評価で表している．樹木の外見的な観察を用 いる手法は，累積的な影響を評価できる利点がある と同時に，さまざまな環境要因が複合的に表現され ているため, 結果の評価が難しい場合もある.しか し, 樹木は, 局地的, 急性的な枯損が認められた公 害, 煙害の時代から, 身近な指標植物として利用さ
れてきている.

東京都においては，1971年（昭和46年）からほほ 5 年間隔で樹木衰退度の調査を実施しており, 1992 年（平成 4 年）までの約 21 年間の推移を大橋らが報 告している.これによれば, 都心部を中心にしたシ イ, シラカシ，ケヤキなどの樹木の衰退の回復傾向 が確認されている。一方，これに反してスギの衰退 は徐々に西部地域へ広がっている状況がわかってい る.そして，大気污染の改善は進んだものの一部で 見られるスギの衰退は, 都市化や開発等による影響 を受けていることが考えられるとしている.

神奈川県においても樹木による植物指標調査を 1973年（昭和48年）に実施した結果，川崎，横浜を 中心にした臨海部の工業地域では，いおう酸化物な どの公害による污染の影響を受け，マツ，ケヤキ， イチョウなどの樹木の衰退が著しい状況であっ た ${ }^{17)}$. 1985年(昭和60年)に行った調査では, クロマ ツ, ケヤキともに12年前に比較して県下全域での,

「活力度」の上昇傾向は認められているものの, な お横浜, 川崎の県東部の臨海部の地域は, 県西部の 地域に比較して, 活力度が低い状況であった ${ }^{18)}$ (図一 4 ).

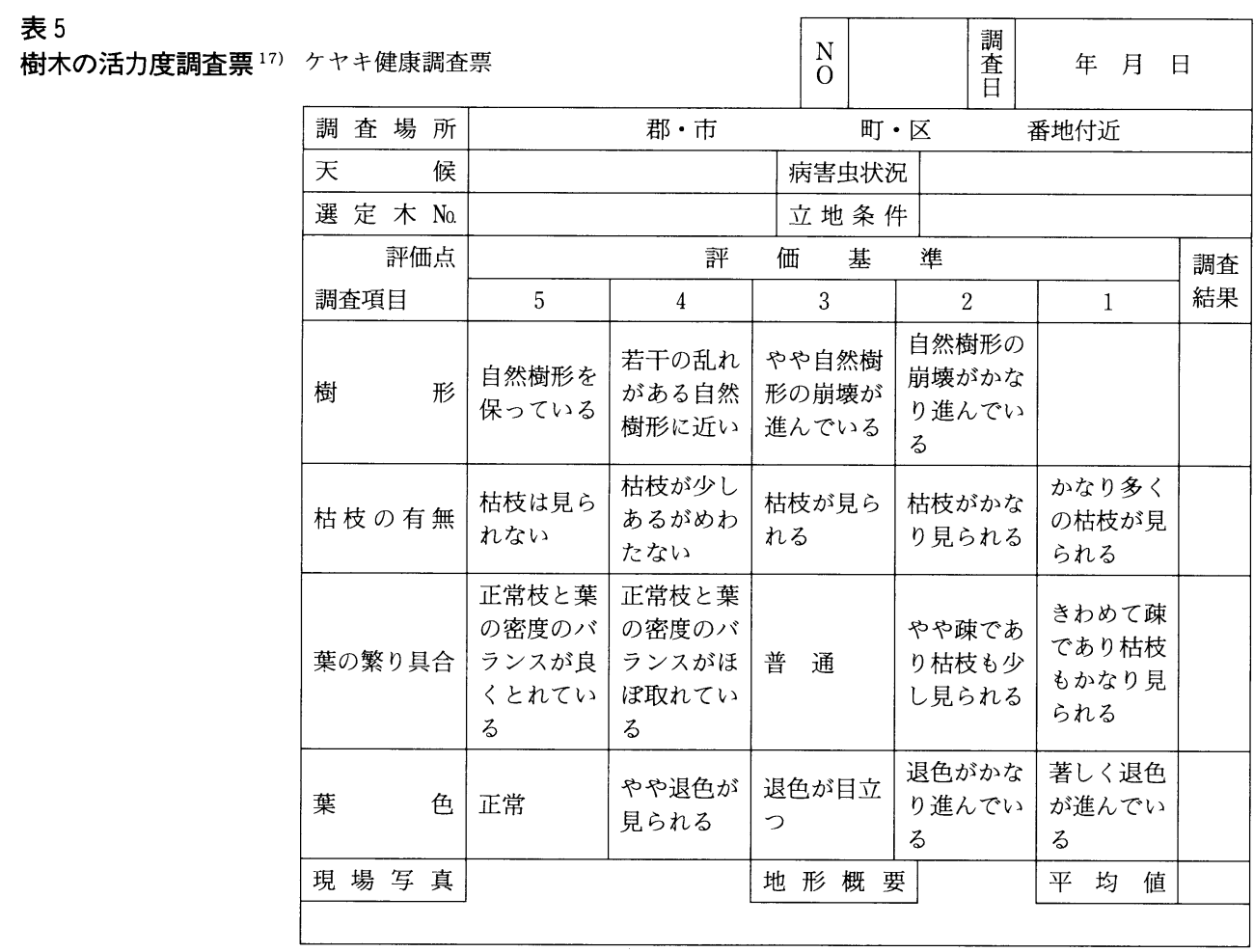



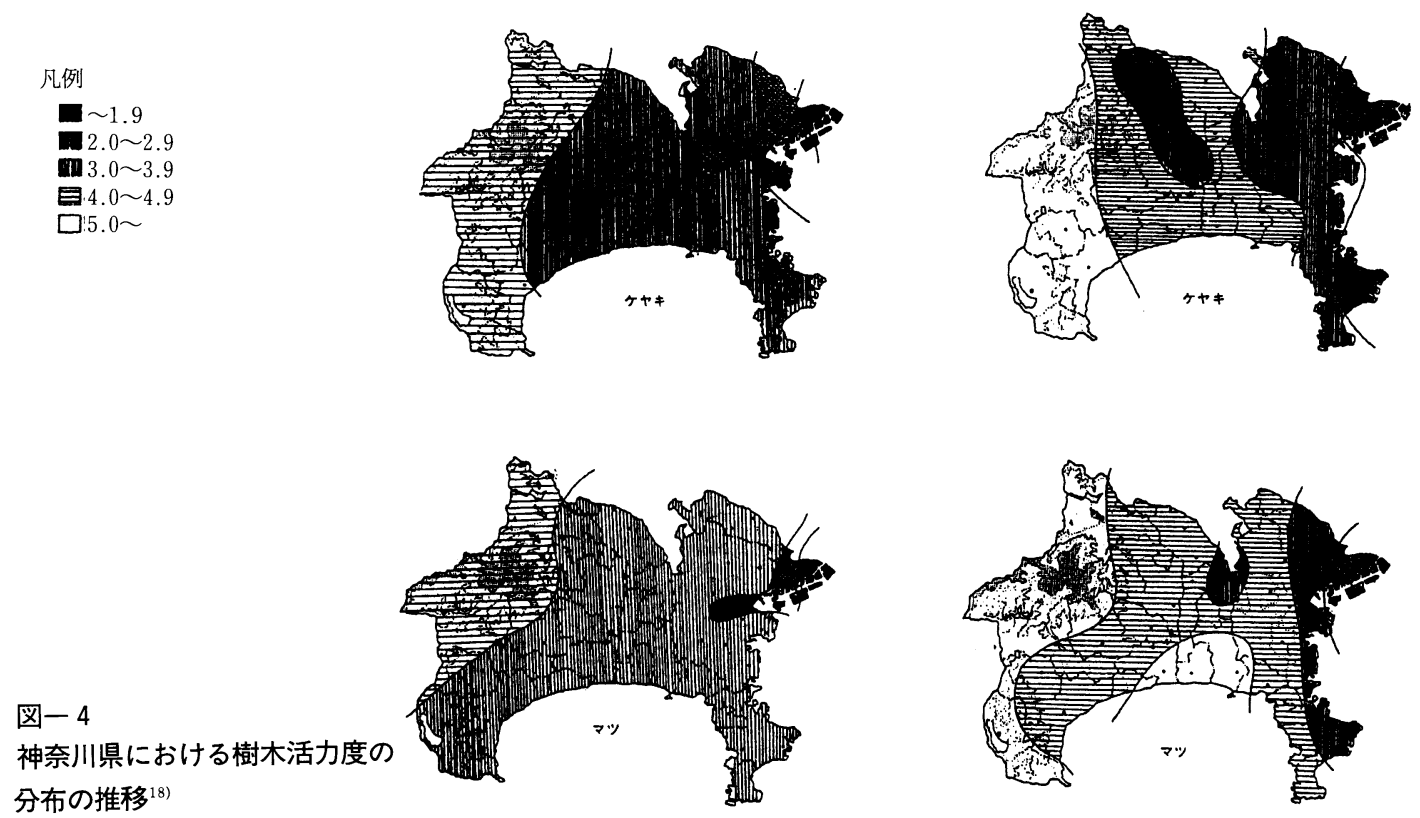

福岡県では, 森林の持つ環境指標性に注目し, 環 境が良好に保たれている社寺林を中心に設定した県 内30カ所の「環境指標の森」でのモニタリング調査 を1973年 (昭和48年) から継続している ${ }^{19)}$ (図一 5 ). 第 1 次 (1973年：昭和 48 年 1981年：昭和 56 年)，第 2 次（1982年：昭和56年～1993年：平成 5 年）を通 じた経年的な調查の結果では ${ }^{20)}$, 台風や虫害, 人為的 攪乱による変化が, 一部で認められるものの, 大気 污染物質などの人為起源物質に起因すると判断され る変化は, いずれの調查地においても認められなか ったとしている.「環境指標の森」が正常な状態で維 持されていることを確認しているものの，環境モ二 タリングを有効に機能させるためには，広域的な調 査とともに，このような定点での，長期的，継続的 調査によるデー夕の蓄積が, 今後も必要であるとし ている.

樹木の観察による方法によっても, 大気污染の著 しかった地域においては, 樹木の活力度が回復して きていることがわかったり, 従来から良好であった 地域では, 活力度の良好な状態が維持されているこ とを確認できている。しかし，樹木に関しては上に のべたような全体的, 経年的な活力度の上昇傾向と ほ裏腹に，20年以上前からの関東地方をはじめとす るスギの衰退・枯損の問題や山間地におけるモミや
ブナなどの森林衰退・枯損現象が顕在化している. これらについては, 様々な面から精力的に調査や研 究が進められており, その因果関係についての説も いくつか出されている. しかし, 未だにはっきりし た結論が得られていない. 大気污染の状況も, 工場 などの固定発生源による 1 次的, 局地的な污染から, 自動車排気ガス問題や光化学污染, 酸性雨現象など に象徵される 2 次的, 広域的な污染へと変化してい る.さらに, 都市化, 温暖化, 乾燥化などに見られ るようにいくつかの要因が複合的に関係しているこ とも示唆されている。このような現状から樹木を指 標植物とした, より広範で, 継続的なモニタリング の実施や調査研究は, 今後とも積極的に進められる べきものと考える.

\section{4.まとめ}

大気污染の評価のための植物指標として,「植物の 葉の可視被害の観察による方法」,「鮮苔植物 (類), 地衣植物（類）等の着生植物による方法」,「樹木の 外見的な観察による方法」をとりあげた。これら以 外にも指標植物を用いた大気污染評価に関する事例 は多く報告され，また提案されてきた。今回話題に 取り上げた方法は, 直接目で植物を観察するという 理解しやすい方法であることもあり，いずれも 10 年 
20年の長期間にわたってモニタリング調査が実際的 に継続実施され，過去からの大気污染環境の変化や 状況を指標植物を通じて評価している数少ない事例 である. 今日，化学物質や物理量の測定のための技 術や装置は，かつてとは比較にならないほど進歩し ている. 大気污染も含めた環境状態の把握は，より 高精度，かつ高度になってきている．このような時 代における植物指標の役割は，簡易な「生物計」と してよりもむしろ「警告」あるいは，生物の立場に 立った「環境評価」としての機能がより重要視され てきている．多くの人間の目によって，簡易に，日 常的に，継続的に，しかもより多くの目によって環 境をモニタリングすることのできる「観察手法によ る植物指標」は，そのための有効な方法のひとつで あると考える．このためには，植物指標の限界と機 能を明らかにすることはもとより,調査手法の統一， 調査の連携，啓発・普及の推進は，不可欠である.

\section{資 料}

1）松中昭一編 ：図説 環境污染と指標生物，朝倉書店 (1980)

2）松中昭一：指標生物， 講談社 (1975)

3）垰田 宏 : 環境污染と指標生物, 共立出版 (1974)

4）大気污染研究全国協議会編：大気污染植物被害写真集,日 本公衆衛生協会 (1973年)

5) 篠崎光夫：神奈川の大気污染をみる(大気污染による植物 被害写真集), 白美堂 (1995)

6）関東地方公害対策推進本部大気污染部会・一都三県公害防 止協議会：平成 7 年度 光化学スモッグによる植物調査
報告書（1996）

7 ）吉村 庸：原色日本地衣植物図鑑，保育社（1974）

8 ) Taoda. H : Mapping of atomospheric pllution in Tokyo based upon epiphitic bryophtes, Jap. J. Ecol., 22, 3, P125-133 (1972)

9 ）菅 邦子, 大橋 毅：樹木着生蘚苔類の生育状況（I ), 東 京都環境研究所年報, 273 (1933)

10）光木偉勝：着生蘚苔植物に基づく大気環境評価指数の推 移, 兵庫県公害研究所研究報告, 第25号, 1 (1993)

11）中川吉弘, 小林樹：着生地衣植物による大気環境評価-10 年前との比較にみられる変化一, 兵庫県公害研究所研究報 告，第27号， 1 (1995)

12）福岡県：着生地衣・蘚苔植生による福岡県内の環境評価 （昭和53年～平成 6 年度）報告，（1995）

13）岸川敏朗, 藤田和男, 生出智哉：ウメノキゴケ類を指標生 物とした神奈川の大気污染, 神奈川県大気污染調查研究報 告, V32,90 (1991)

14）神奈川県臨海地区大気污染協議会：大気污染生物指標調 查, 平成 5 年度神奈川県臨海地区大気污染協議会報告書, P73 (1993)

15）大橋 毅，菅 邦子 地衣類（ウメノキゴケ等）の生育状 況について，東京都環境科学研究所年報，228（1994）

16）大橋 毅, 菅 邦子：都内のスギ，ケヤキ生育調査，東京 都環境科学研究所年報, 338 (1995)

17）神奈川県公害対策事務局・神奈川県農業総合研究所：リモ ートセンシングによる大気污染の地域評価, 神奈川県大気 污染調查調查研究報告 V17，P88（1980）

18）神奈川県環境部・神奈川県公害センター・神奈川県農業総 合研究所：神奈川県における樹木の活力度一生物が教え てくれる大気污染一, 神奈川県大気污染調査調査研究報告 V29，P119（1988年）

19）福岡県：福岡県環境指標の森 昭和 $48 ＼mathrm{~ 56 年 度 調 査 総 合 ~}$ 報告書, （1983）

20) 福岡県： 福岡県環境指標の森 第 2 次調査 (昭和 57 平 成 5 年度) 報告書, (1995) 